\title{
Polycomb protein Ezh2 regulates pancreatic $\beta$-cell Ink4a/Arf expression and regeneration in diabetes mellitus
}

\author{
Hainan Chen, ${ }^{1}$ Xueying Gu, ${ }^{1}$ I-hsin Su, ${ }^{2,6}$ Rita Bottino, ${ }^{3}$ Juan L. Contreras, ${ }^{4}$ Alexander Tarakhovsky, ${ }^{2}$ \\ and Seung K. Kim ${ }^{1,5,7}$ \\ ${ }^{1}$ Department of Developmental Biology, Stanford University School of Medicine, Stanford, California 94305, USA; ${ }^{2}$ Laboratory of \\ Lymphocyte Signaling, The Rockefeller University, New York, New York 10065, USA; ${ }^{3}$ Department of Pediatrics, Division of \\ Immunogenetics, Diabetes Institute, University of Pittsburgh, School of Medicine, Pittsburgh, Pennsylvania 15213, USA; \\ ${ }^{4}$ Department of Surgery, Division of Transplantation, University of Alabama School of Medicine, Birmingham, Alabama 35294, \\ USA; ${ }^{5}$ Howard Hughes Medical Institute and Department of Medicine, Oncology Division, Stanford University School of \\ Medicine, Stanford, California 94305, USA
}

Proliferation of pancreatic islet $\beta$ cells is an important mechanism for self-renewal and for adaptive islet expansion. Increased expression of the Ink4a/Arf locus, which encodes the cyclin-dependent kinase inhibitor $\mathbf{p 1 6}^{\text {INK4a }}$ and tumor suppressor p19 $^{\text {Arf }}$, limits $\beta$-cell regeneration in aging mice, but the basis of $\beta$-cell Ink4a/Arf regulation is poorly understood. Here we show that Enhancer of zeste homolog 2 (Ezh2), a histone methyltransferase and component of a Polycomb group (PcG) protein complex, represses Ink4a/Arf in islet $\beta$ cells. Ezh2 levels decline in aging islet $\beta$ cells, and this attrition coincides with reduced histone $\mathrm{H} 3$ trimethylation at Ink4a/ Arf, and increased levels of p16 ${ }^{\mathrm{INK} 4 \mathrm{a}}$ and p19 ${ }^{\mathrm{Arf}}$. Conditional deletion of $\beta$-cell Ezh2 in juvenile mice also reduced $\mathrm{H} 3$ trimethylation at the Ink4a/Arf locus, leading to precocious increases of $\mathrm{p}^{\mathrm{INK}}{ }^{\mathrm{INa}}$ and $\mathrm{p}^{\mathrm{Arf}}$. These mutant mice had reduced $\beta$-cell proliferation and mass, hypoinsulinemia, and mild diabetes, phenotypes rescued by germline deletion of Ink4a/Arf. $\beta$-Cell destruction with streptozotocin in controls led to increased Ezh2 expression that accompanied adaptive $\beta$-cell proliferation and re-establishment of $\beta$-cell mass; in contrast, mutant mice treated similarly failed to regenerate $\beta$ cells, resulting in lethal diabetes. Our discovery of Ezh2-dependent $\beta$-cell proliferation revealed unique epigenetic mechanisms underlying normal $\beta$-cell expansion and $\beta$-cell regenerative failure in diabetes pathogenesis.

[Keywords: Pancreas; islet of Langerhans; histone; epigenetics; diabetes; cell cycle]

Supplemental material is available at http://www.genesdev.org.

Received September 18, 2008; revised version accepted March 13, 2009.

Proliferation of insulin-secreting $\beta$ cells in pancreatic islets is an important mechanism for establishing, maintaining, and adapting islet organ function to meet host physiological demands (for review, see Cozar-Castellano et al. 2006; Heit et al. 2006a). Harnessing our understanding of these mechanisms could accelerate development of islet replacement strategies in diseases like autoimmune (type 1) diabetes, but the molecular basis of self-renewal in organs like islets is poorly understood. Islet $\beta$ cells expand in neonatal humans, mice, and other species, but this proliferation decays thereafter (Teta et al. 2005; Meier et al. 2008), which may promote pandemic (type 2) forms of diabetes mellitus. Thus, investigation of

${ }^{6}$ Present address: Division of Genomics and Genetics, School of Biological Sciences, Nanyang Technological University, Singapore 639798. ${ }^{7}$ Corresponding author.

E-MAIL seungkim@stanford.edu; FAX (650) 725-7739.

Article is online at http://www.genesdev.org/cgi/doi/10.1101/gad.1742509. regenerative failure in $\beta$ cells may elucidate important mechanisms underlying diabetes pathogenesis.

p $16^{\text {INK4a }}$ and p19 Arf (hereafter Ink4a and Arf) encoded by the $C d k n 2 a$ locus are negative regulators of the cell cycle and are thought to limit proliferation in islet $\beta$ cells (Krishnamurthy et al. 2006) and other tissues (Zindy et al. 1997). Ink4a inhibits specific cyclin-dependent kinases $(\mathrm{CDK})$, including CDK4, a key regulator of $\beta$-cell proliferation (Rane et al. 1999), while Arf inhibits the ubiquitin ligase activity of MDM2, thereby stabilizing p53 (for review, see Matheu et al. 2008). Germline Ink4a deficiency in mice permits increased $\beta$-cell proliferation, supporting the conclusion that Ink4a constrains $\beta$-cell proliferation in mice (Krishnamurthy et al. 2006). Moreover, genome-wide association studies in humans link the CDKN2A locus to type 2 diabetes susceptibility (Grarup et al. 2007; Saxena et al. 2007; Scott et al. 2007; Zeggini et al. 2007; Omori et al. 2008). However, it remains unclear if $C D K N 2 A$ expression changes in 
human islets, and how this locus is regulated in islet $\beta$ cells or other tissues in vivo.

Polycomb group (PcG) proteins are evolutionarily conserved factors that form heteroprotein complexes that modify chromatin structure and gene expression (Ringrose and Paro 2007). Prior studies suggest that PcG proteins are involved in regulating embryonic development, stem cell renewal, and tumor pathogenesis (for review, see Sparmann and van Lohuizen 2006). Two distinct Polycomb-Repressive Complexes, PRC1 and PRC2, have been identified. The PcG protein Enhancer of zeste homolog 2 (Ezh2) functions as a histone methyltransferase in PRC2, which contains Eed, Suz12, and other proteins (Cao et al. 2002). PRC2 initiates and maintains methylation of histone H3 on Lys27 (H3K27), an epigenetic mark that mediates transcriptional repression of chromatin, in part by recruitment of histone deacetylases (van der Vlag and Otte 1999). Recent studies revealed that Ezh2-dependent H3K27 trimethylation (H3K27me3) represses target genes like Ink4a/Arf to control growth of cancer cell lines and embryonic fibroblasts (Bracken et al. 2003, 2007), but the role of Ezh2 in physiological expansion or regeneration of organs like pancreatic islets has not been reported, to our knowledge. Here we show that Ezh2 is required to regulate histone methylation and repression of the Ink4a/Arf locus in pancreatic islets, thereby permitting physiological islet $\beta$-cell expansion in neonatal mice, and adaptive $\beta$-cell regeneration after conditional chemical ablation of $\beta$-cell in adults, functions that may prevent $\beta$-cell replication failure and diabetes mellitus pathogenesis.

\section{Results}

\section{Declining Ezh2 levels accompany reduced proliferation} by pancreatic islet $\beta$ cells

$\beta$-Cell proliferation in pancreatic islets declines with age in rodents and humans, with the sharpest reductions in juveniles (Teta et al. 2005; Krishnamurthy et al. 2006; Meier et al. 2008). Reduced $\beta$-cell proliferation in mice corresponds with increased islet expression of Ink $4 a$ and $\operatorname{Arf}$ (Fig. 1A,B,D; Nielsen et al. 1999; Krishnamurthy et al. 2006). Prior studies suggest that PcG proteins regulate Ink4a/Arf expression and proliferation in cultured fibroblasts (Bracken et al. 2003, 2007). To investigate possible roles in proliferation of pancreatic $\beta$ cells, we examined expression of genes encoding PcG proteins, including Ezh1,Ezh2, Eed, Suz12, Cbx4, and Phc1 in islets isolated from C57BL/6 mice (Fig. 1C,D; Supplemental Fig. 1). Using real-time RT-PCR, we found that mRNA encoding each of these factors was detectable in mouse pancreatic islets from birth to $1 \mathrm{yr}$ of age (Supplemental Fig. 1). Unlike other PcG factors tested, levels of Ezh2 mRNA declined during this period, marked by a rapid reduction in neonatal and juvenile mice, followed by a slower decline in aging adults (Fig. 1C). Immunohistology allowed detection of Ezh2 protein in islet $\beta$-cell nuclei (Fig. 1E-G) and revealed that Ezh2 protein level in $\beta$ cells from 384-d-old mice (Fig. 1H-J) was reduced compared
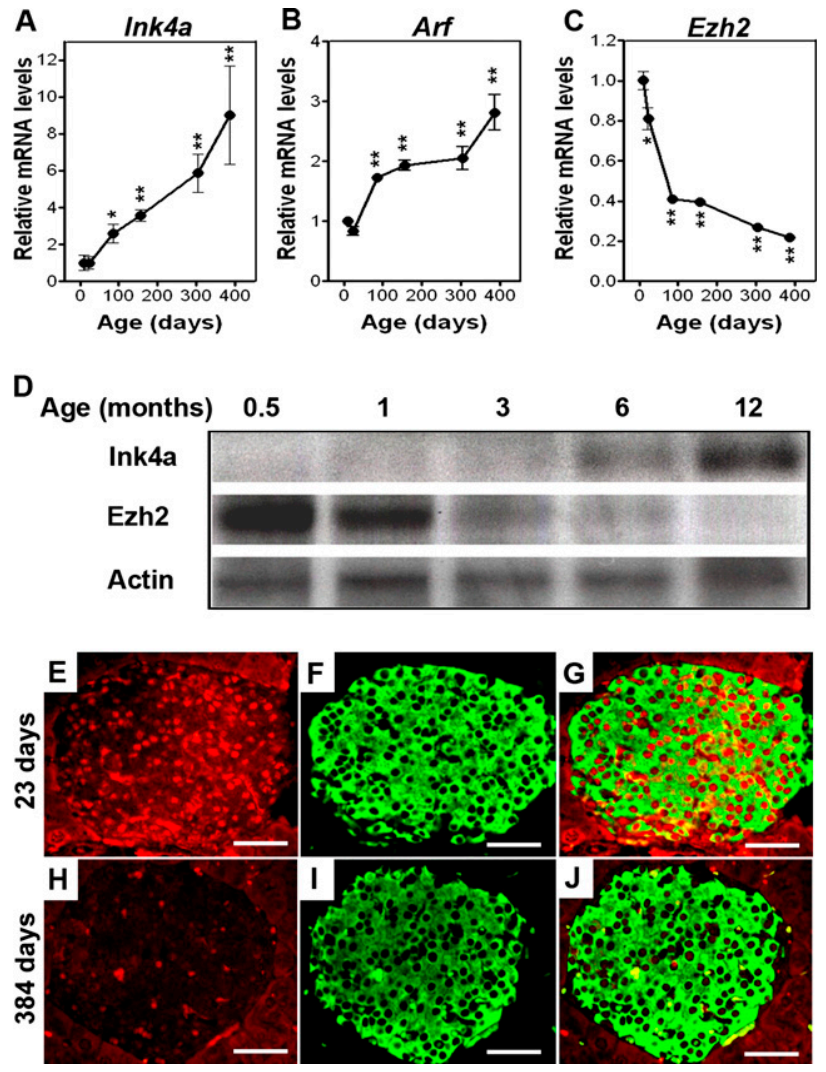

Figure 1. Declining Ezh2 expression accompanies increased Ink $4 a / A r f$ expression in mouse pancreatic $\beta$ cells during aging. Relative mRNA levels of $\operatorname{Ink} 4 a(A), \operatorname{Arf}(B)$, and Ezh2 $(C)$ in mouse pancreatic islets at the indicated ages, as determined by real-time RT-PCR. $n=3$ to 10 mice per time point. $\left({ }^{\star}\right) P<0.05$, $\left(^{\star \star}\right) P<0.01$ compared with values derived from islets of 10 -dold mice. $(D)$ Representative Western blot analysis of the indicated proteins in islets from mice at the indicated ages. Each lane contains total protein from an individual mouse islet lysate. $(E-J)$ Representative images of pancreatic islets and adjacent tissues following immunostaining for Ezh2 (red) and insulin (green) in young (23-d-old, E-G) and old (384-d-old, $H-J)$ mice. $G$ is a merged image of $E$ and $F$, and $J$ is a merge of $H$ and $I$. Bar, $25 \mu \mathrm{m}$.

with $\beta$ cells from 23-d-old mice (Fig. 1E-G), a result corroborated by Western blotting of islet proteins (Fig. 1D). Likewise, RT-PCR analysis of isolated human islets revealed age-dependent reduction of EZH2 mRNA compared with SUZ12, with the greatest reductions occurring in juveniles, followed by a slower decline in adults (Fig. $2 \mathrm{~A}, \mathrm{~B})$. Immunohistology revealed EZH2 protein reduction and INK4A increase in human pancreatic $\beta$ cells with advancing age (Fig. 2C-J). Consistent age-dependent reductions of Ezh2 in vivo have only been reported previously in the kidney (Metsuyanim et al. 2008).

\section{Histone modifications at the Ink4a/Arf locus accompany Ezh2 loss in $\beta$ cells}

Ezh2-dependent H3K27me3 represses Ink4a/Arf expression in cultured cells (Bracken et al. 2007), but to our 

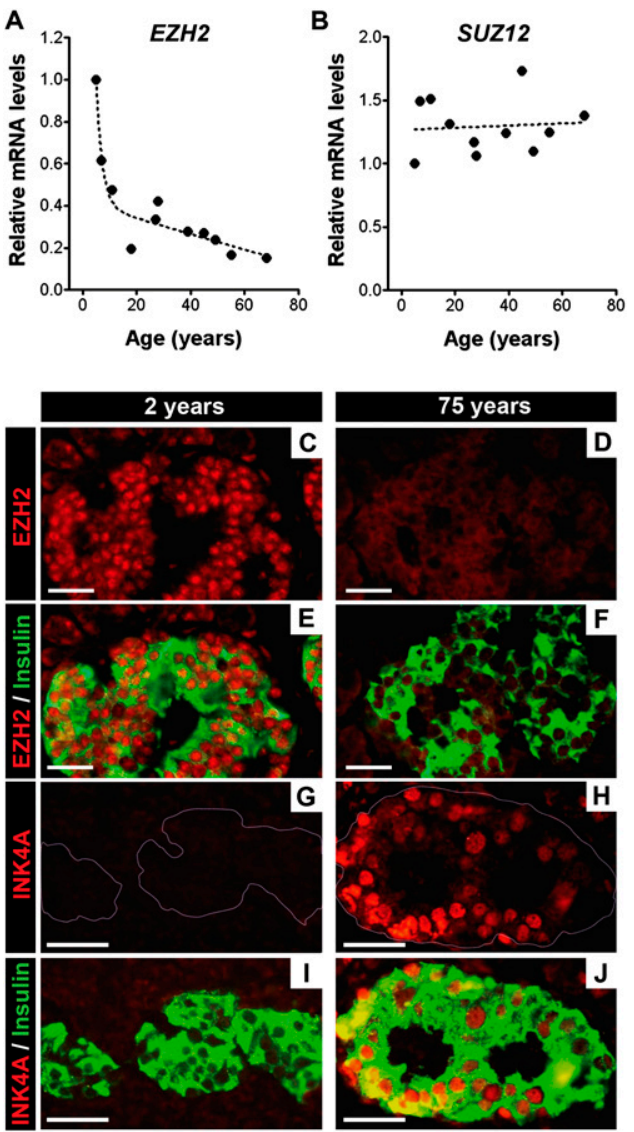

Figure 2. Decreased $E Z H 2$ expression in aging is conserved in human pancreatic islet $\beta$ cells. Relative mRNA levels of $E Z H 2$ $(A)$ and $S U Z 12(B)$ in human pancreatic islets at the indicated ages, as determined by real-time RT-PCR. Each dot represents the value from an individual subject. $(C-I)$ Representative images of pancreatic islets and adjacent tissues following immunostaining for EZH2 (red), INK4A (red) and insulin (green) in 2-yr-old $(C, E, G, I)$ and 75 -yr-old $(D, F, H, J)$ subjects. Similar results were obtained with repeated observations of pancreas sections from three young donors $(<10 \mathrm{yr}$ old $)$ and three older donors (>60 yr old). Bar, $25 \mu \mathrm{m}$.

knowledge, PRC2 regulation of Ink4a/Arf expression or associated in vivo histone modifications in islets has not been reported. To assess if pancreatic islet Ezh2 reduction leads to increased islet expression of Ink4a and Arf, we performed chromatin immunoprecipitation (ChIP) on isolated mouse islets. These studies revealed direct association of Ezh2 with Ink4a/Arf and with the linked $C d k n 2 b$ gene encoding the CDK inhibitor $\mathrm{p} 15^{\text {Ink } 4 \mathrm{~b}}$ (Ink4b) (Fig. 3A,B). Compared with islets from 1-mo-old mice, we found reduced levels of Ezh2 protein and H3K27me3 associated with both Ink4a and Arf in islets from mice aged 11 mo (Fig. 3B,C), suggesting that attenuated Ezh2 levels and function may contribute to increased Ink4a/Arf expression in mouse pancreatic islets. In addition, we detected significantly increased histone H3K4me3 and histone acetylation at the Ink4a/ Arf locus in older mice (Fig. 3D,E), but no significant change in levels of $\mathrm{H} 3 \mathrm{~K} 9 \mathrm{me} 3$ or control $\mathrm{IgG}$ association
(Fig. 3F,G). Since the catalytic subunit Ezh2 of the PRC2 complex specifically methylates histone H3 at Lys27 (Cao et al. 2002; Su et al. 2003), we conclude that Ezh2 loss indirectly affects $\mathrm{H} 3 \mathrm{~K} 4$ methylation and $\mathrm{H} 3$ acetylation at Ink4a/Arf. In contrast, association of Ezh2, $\mathrm{H} 3 \mathrm{~K} 27 \mathrm{me} 3, \mathrm{H} 3 \mathrm{~K} 4 \mathrm{me} 3$, and $\mathrm{H} 3$ acetylation with $p 15^{\text {Ink } 4 b}$ was not significantly altered in young and older mice (Fig. 3B-E), consistent with the finding that pancreatic islet $p 15^{\text {Ink } 4 b}$ mRNA levels did not change in aging mice (Krishnamurthy et al. 2006).

\section{Conditional Ezh2 inactivation in islet $\beta$ cells induces premature Ink4a/Arf expression}

Several signaling pathways influence expression of the Ink4a/Arf locus (for review, see Kim and Sharpless 2006). To determine whether Ezh2 regulates Ink4a/Arf expression in vivo, we generated mice that permitted conditional Ezh2 loss in $\beta$ cells. Transgenic mice producing Cre recombinase in $\beta$ cells (RIP-Cre) (Herrera 2000; Heit et al. 2006b) were intercrossed with mice harboring a floxed Ezh2 allele (Su et al. 2003) to generate progeny with the RIP-Cre; Ezh2 ${ }^{f / f}$ genotype (abbreviated $\beta E z h 2 \mathrm{KO}$ ). Littermate control islets expressed Ezh2 mRNA and Ezh2 protein in $\beta$ cells, but $\beta E z h 2 \mathrm{KO}$ islets were deficient for Ezh2 mRNA, and $\beta$ cells lacked Ezh2 as judged by realtime RT-PCR and immunostaining (Fig. 4A,B), results corroborated by Western blotting of islet proteins (Supplemental Fig. 2A). In contrast, islet mRNA levels of Bmi-1 and Suz12, and Ezh2 protein levels in pancreatic non- $\beta$ cells (e.g., acinar cells) were indistinguishable in $\beta$ Ezh2KO and littermate control mice (Fig. 4A,B). Levels of Ink4a protein were increased in $\beta$ Ezh2KO $\beta$ cells (Fig. 4C), and mRNA levels of Ink $4 a$ and Arf were increased in $\beta E z h 2 K O$ islets compared with control littermates (Fig. 4D,E). Thus, conditional Ezh2 loss in $\beta$ cells led to derepression of established Ezh2 targets. Consistent with these findings, ChIP studies of islets from 1-mo-old $\beta$ Ezh2KO mice revealed severe, premature reduction of Ezh2 and H3K27me3 levels (Fig. 4F,G) and increased H3K4me3 (Fig. 4H) and H3 acetylation (Supplemental Fig. 2C) associated with Ink4a/Arf. Thus, Ezh2 is required to maintain $\mathrm{H} 3 \mathrm{~K} 27$ methylation and repression of the Ink $4 a /$ Arf locus in pancreatic $\beta$ cells. In contrast, we did not detect changes in expression of mRNAs encoding other members of the Ink4 or Cip/Kip families of CDK inhibitors, levels of $\mathrm{H} 3 \mathrm{~K} 9 \mathrm{me} 3$ or control IgG associated with Ink4a/Arf (Supplemental Fig. 2B,D,E), indicating that Ezh2 may have a unique role in controlling expression of $\beta$-cell cycle regulators. Islet Ink $4 a / A r f$ expression increased in aging $\beta$ Ezh2KO mice (Fig. 4D,E), although the level of this increase was blunted compared with controls; thus, Ezh2-independent mechanisms are likely to regulate Ink4a and Arf levels in mouse islets.

\section{$\beta$-Cell hypoplasia and mild diabetes mellitus in $\beta E z h 2 K O$ mice}

To assess the physiological effects of Ezh2 inactivation in $\beta E z h 2 \mathrm{KO}$ mice, we measured blood glucose levels after 
Chen et al.

A

Mouse Cdkn2a/2b locus

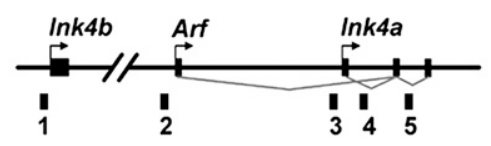

D

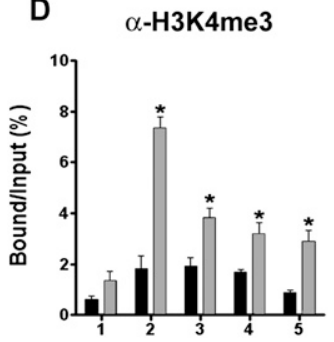

E

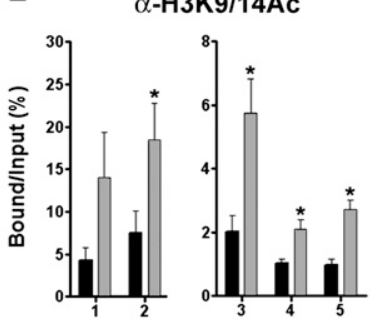

B

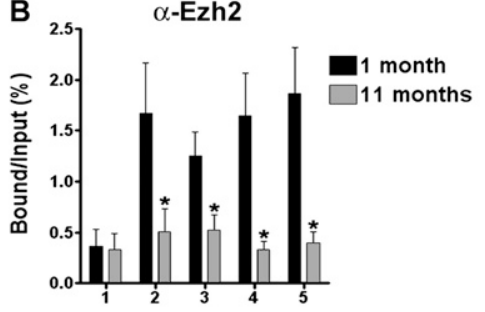

$\mathbf{F}$

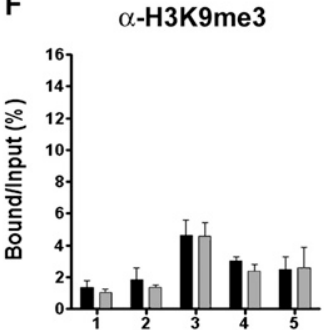

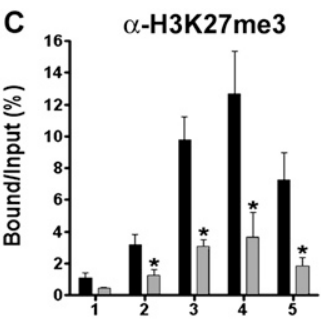

G

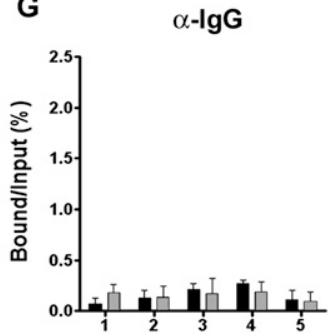

Figure 3. Dynamic Ezh2 association and histone modification at the Ink $4 a /$ Arf locus in aging pancreatic islets. $(A)$ A schematic of the mouse Cdkn2a/2b locus that encodes the linked mouse genes Ink4a, Arf, and Ink4b. The relative position of amplicons (1, 2, 3, 4, and 5) used for ChIP assays is marked by black bars. Primer sequences were listed in Supplemental Table 2. ChIP analysis was performed with the indicated amplicons and antibodies recognizing Ezh2 $(B)$, H3K27me3 $(C)$, H3K4me3 $(D)$, H3K9/14Ac $(E)$, H3K9me3 $(F)$, and IgG control $(G)$ in pancreatic islets purified from young (1-mo-old) and old (10 12-mo-old, Avg. $11 \mathrm{mo})$ C57BL/6 mice. DNA enrichments are presented as percentages of total input. Three to five independent ChIP experiments were performed for each antibody using separate islet preparations. $\left(^{\star}\right) P<0.05$ for 1 mo versus 11 mo.

overnight fasting and refeeding. Littermate controls, including those harboring the RIP-Cre transgene used in these studies (Herrera 2000; Heit et al. 2006b), maintained normoglycemia, but $\beta E z h 2 \mathrm{KO}$ mice had significant hyperglycemia by $4-6 \mathrm{wk}$ of age, including post-prandial hyperglycemia exceeding $200 \mathrm{mg} / \mathrm{dL}$, an established criterion for diabetes in humans (Fig. 5A,B). Although this impaired glucose regulation improved modestly with aging, we observed persistent postprandial hyperglycemia and diabetes in older $\beta E z h 2 \mathrm{KO}$ mice (Fig. 5B; Supplemental Fig. 3D). Likewise acute glucose challenge by intraperitoneal injection following overnight fasting revealed significantly elevated blood glucose levels and prolonged hyperglycemia in $\beta E z h 2 \mathrm{KO}$ mice compared with littermate controls (Fig. 5C,D; Supplemental Fig. 3B,C), defects that persisted in $\beta E z h 2 K O$ mice throughout adulthood (Supplemental Fig. 3E). In contrast, body mass and insulin sensitivity were not detectably altered in $\beta E z h 2 K O$ mice (Supplemental Fig. 3A,F). Thus, Ezh2 in $\beta$ cells is essential for maintaining normoglycemia, and Ezh2 deficiency in $\beta$ cells resulted in mild, nonlethal diabetes mellitus. Following an overnight fast or after glucose challenge, $\beta E z h 2 \mathrm{KO}$ mice had a $50 \%$ reduction in plasma insulin levels compared with littermates (Fig. 5E). Consistent with their postnatal hypoinsulinemia, $\beta E z h 2 \mathrm{KO}$ mice had reduced insulin content from 1 mo of age compared with control littermates (Fig. 5F). In contrast, insulin content in whole pancreas from newborn $\beta E z h 2 \mathrm{KO}$ mice (P1) was indistinguishable from littermates (Fig. 5F), indicating that $\beta$-cell development is not detectably impaired in $\beta$ Ezh2KO mice. Likewise, islet $\beta$-cell insulin content and insulin secretion by isolated islets challenged with glucose or amino acids were indistinguishable in $\beta$ Ezh2KO mice and controls (Supplemental Fig. 3G-I).

To test whether reduced pancreatic insulin content in $\beta E z h 2 K O$ mice reflected decreased $\beta$-cell mass, we assessed the pancreata of these mice and littermate controls at birth, $1 \mathrm{mo}$, and $4 \mathrm{mo}$ of age. The mass of $\beta$ cells in newborn mice was not significantly different between $\beta$ Ezh2KO and littermate control mice (Fig. 5G). $\beta$-Cell mass in $\beta E z h 2 \mathrm{KO}$ mice at $1 \mathrm{mo}$ of age, however, was reduced compared with littermate controls $(P<0.01)$ (Fig. 5G). Likewise, incorporation of bromodeoxyuridine (BrdU) in $\beta E z h 2 K O$ mice at 1 mo showed that $\beta$-cell proliferation was reduced (Fig. 5H,I). Compared with controls, we did not detect changes in $\beta$-cell size in $\beta E z h 2 K O$ mice $\left(113 \pm 3.6 \mu \mathrm{m}^{2}\right.$ for $\beta$ Ezh2KO; $120 \pm 3.3$ $\mu \mathrm{m}^{2}$ for littermate controls, $\left.P>0.05\right)$. Thus, Ezh2 is essential for $\beta$-cell proliferation and establishing appropriate $\beta$-cell mass in juvenile mice. Mild hyperglycemia in mice is known to stimulate $\beta$-cell proliferation (Alonso et al. 2007), and we observed that $\beta$-cell mass and pancreatic insulin content increased in $\beta E z h 2 \mathrm{KO}$ mice as they aged (Fig. 5F,G). This late phase of $\beta$-cell expansion did not re-establish normal $\beta$-cell mass or glucose control in $\beta$ Ezh2KO mice (Supplemental Fig. 3). Nevertheless, our data also provide evidence for Ezh2-independent mechanisms that regulate $\beta$-cell expansion.

\section{Cdkn2a inactivation restores normoglycemia and $\beta$-cell expansion in $\beta E z h 2 \mathrm{KO}$ mice}

We postulated that increased expression of Ink4a/Arf encoded by the $C d k n 2 a$ locus might promote diabetes pathogenesis in $\beta E z h 2 \mathrm{KO}$ mice; we therefore tested 

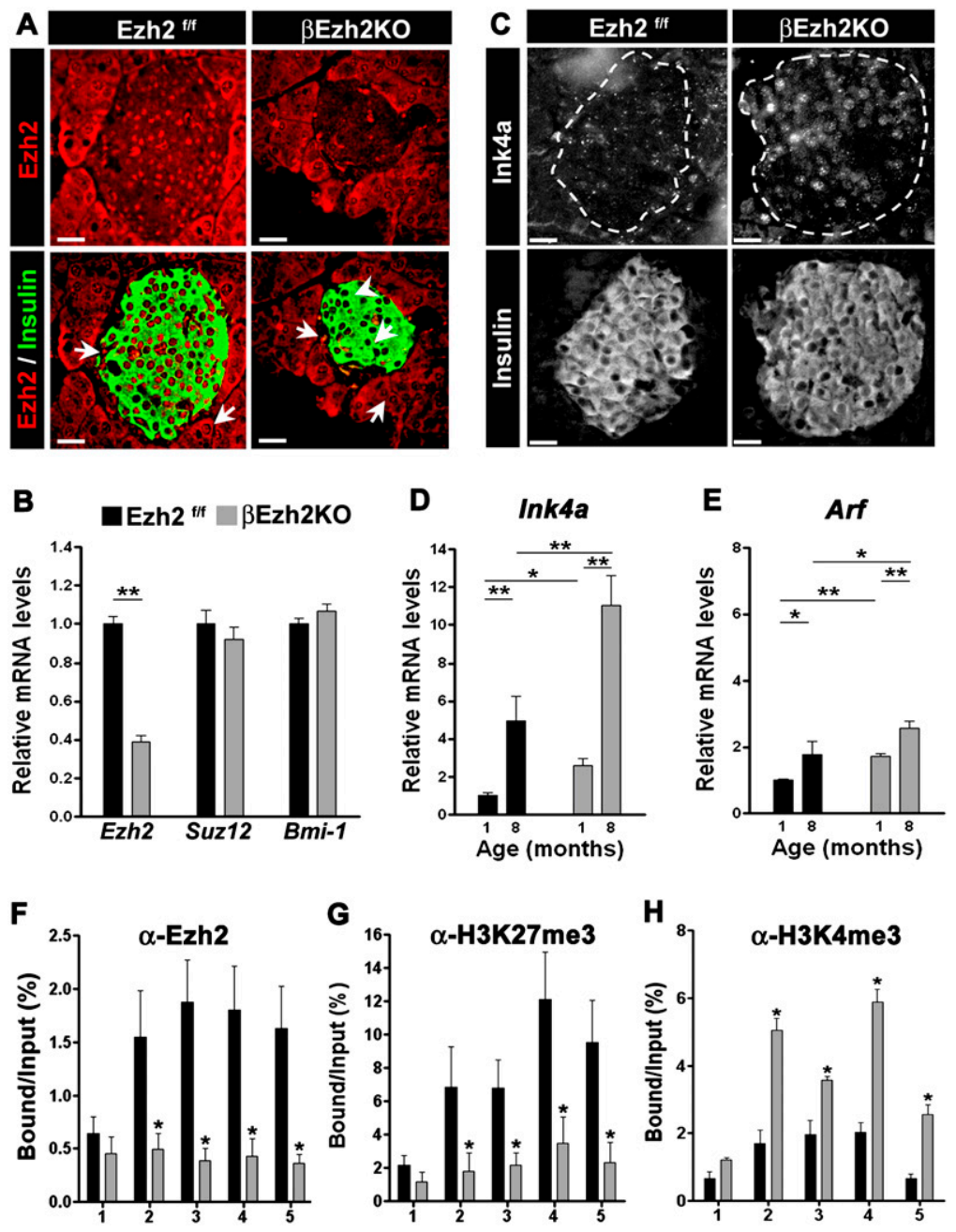

Figure 4. Premature increase of Ink4a/Arf expression in pancreatic $\beta$ cells lacking Ezh2. (A) Immunofluorescence staining of Ezh2 and insulin in pancreas sections from $\beta E z h 2 \mathrm{KO}$ and control $\left(E z h 2^{\mathrm{f} / \mathrm{f}}\right)$ mice at $1 \mathrm{mo}$ of age. Ezh2 in $\beta$ Ezh2KO islet $\beta$ cells that express insulin (arrowheads) is markedly reduced compared with levels in non- $\beta$ cells (arrows), or in islet $\beta$ cells of control mice. (B) Relative mRNA levels of Ezh2, Suz12, and Bmi-1 in control $\mathrm{Ezh}^{\mathrm{f} / \mathrm{f}}$ and $\beta E z h 2 \mathrm{KO}$ islets from 1-mo-old mice, as measured by real-time RT-PCR. (C) Immunostaining of Ink4a and insulin in pancreas sections from 1mo-old mice. $(D, E)$ Relative mRNA levels of Ink $4 a$ $(D)$ and $A r f(E)$ in isolated islets from control Ezh2 $2^{\mathrm{f} / \mathrm{f}}$ and $\beta E z h 2 K O$ mice. $n=4-10$ mice per group. $(F-H)$ ChIP analysis of the Ink $4 b$ and Ink $4 a /$ Arf loci using the indicated amplicons (shown in Fig. 3A) and antibodies in islets from 1-mo-old control Ezh2 ${ }^{\mathrm{f} / \mathrm{f}}$ and $\beta E z h 2 K O$ mice. Three to five independent ChIP experiments were performed for each antibody using separate islet preparations. $\left(^{\star}\right) P<0.05,\left(^{\star \star}\right) P<$ 0.01 for $\beta E z h 2 K O$ versus control Ezh2 $2^{1 / f}$ or for comparisons indicated. Bar, $25 \mu \mathrm{m}$. whether germline Cdkn2a loss in $\beta$ Ezh2KO mice could prevent $\beta$-cell replication failure and diabetes pathogenesis. We intercrossed mice to generate RIP-Cre; Ezh2 ${ }^{\mathrm{f} / \mathrm{f}}$; $C d k n 2 a^{-1-}$ (abbreviated $\beta E z h 2 K O ; C d k n 2 a^{-1-}$ ) and littermate control mice. Unlike $\beta$ Ezh2KO littermates, which developed fasting hyperglycemia and overt postprandial diabetes by 4 wk, $\beta$ Ezh2KO; $C d k n 2 a^{-1-}$ mice maintained normal glucose levels during fasting and random feeding (Fig. 6A; data not shown). Similarly, fasted $\beta E z h 2 K O ; C d k n 2 a^{-1-}$ mice challenged with intraperitoneal glucose showed no evidence of impaired tolerance (Fig. 6B,C). Consistent with these findings, serum insulin levels during glucose challenge in $\beta$ Ezh2KO; Cdkn2a $a^{-1-}$ mice did not differ significantly from those in nondiabetic control littermates (Fig. 6D). Thus, Cdkn2a deficiency was sufficient to restore normoglycemia and insulin levels to mice lacking $\beta$-cell Ezh2. Moreover, pancreatic insulin content and $\beta$-cell mass, and $\beta$-cell proliferation in $\beta$ Ezh2KO; $C d k n 2 a^{-/-}$ mice and littermate controls were indistinguishable (Fig. 6E-G). Taken together, these data indicate that increased Ink4a/Arf expression, resulting in reduced $\beta$-cell proliferation, is a principal cause of premature diabetes onset in $\beta E z h 2 \mathrm{KO}$ mice.
Impaired $\beta$-cell regeneration and severe diabetes after streptozotocin (STZ) challenge in $\beta E z h 2 K O$ mice

Diabetes pathogenesis is a complex process that reflects $\beta$-cell adaptations to systemic stress. Destruction of $\beta$ cells by toxins like STZ can lead to diabetes and subsequent regenerative $\beta$-cell expansion with restoration of $\beta$-cell mass in mice (Wang et al. 1996; Krishnamurthy et al. 2006). We treated mice with STZ to examine islet Ezh2 expression and function in adult $\beta$-cell regeneration and diabetes pathogenesis. Following STZ-induced $\beta$-cell destruction, Ezh2 mRNA and protein levels increased in surviving islet $\beta$ cells (Fig. 7A,B). Consistent with our other observations that Ink4a/Arf expression is repressed by Ezh2, we observed reduced Ink4a and Arf mRNA levels in islets from STZ-challenged mice (Fig. 7C). However, by $15 \mathrm{~d}$ after STZ challenge, immunohistochemical detection showed elevated levels of nuclear Ink4a protein in $\beta$ Ezh2KO islet $\beta$ cells compared with those from controls (Fig. 7D), supporting the possibility that Ezh2 is required for repression of Ink4a/Arf expression during $\beta$-cell regeneration.

To assess if Ezh2 is required for adaptive $\beta$-cell regeneration following STZ, we assessed $\beta$-cell proliferation 
Chen et al.
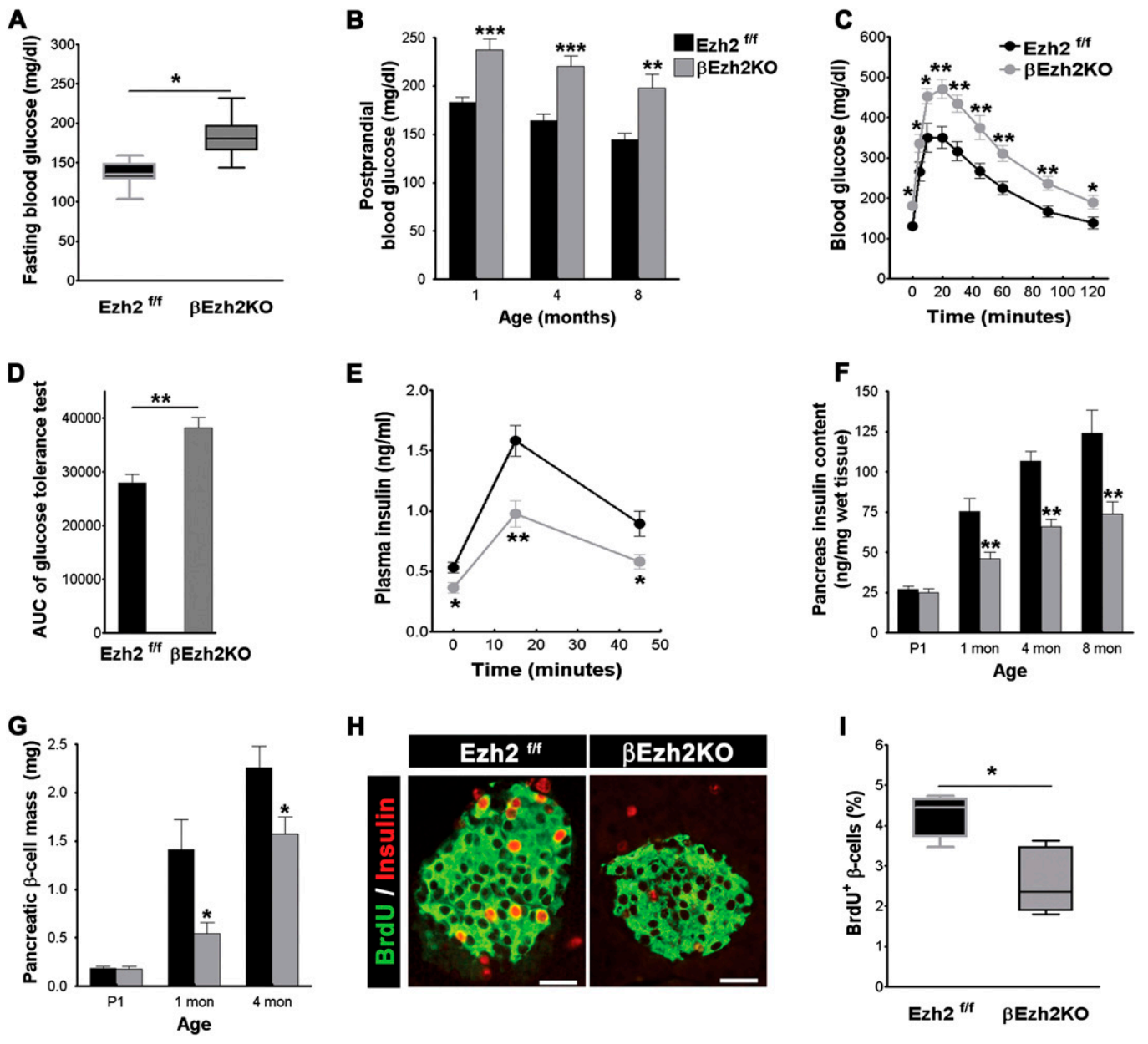

Figure 5. $\beta$-cell hypoplasia and mild diabetes mellitus in $\beta$ Ezh2KO mice. $(A)$ Fasting blood glucose levels in 1 -mo-old mice. $n=15-18$ for each group. (B) Post-prandial blood glucose levels in male $\beta$ Ezh2KO and littermate control Ezh2 ${ }^{\mathrm{f} / \mathrm{f}}$ mice at the indicated age. $n=10-$ 16 for each group. $(C)$ Glucose tolerance testing performed on 1-mo-old mice after an intraperitoneal injection of $3 \mathrm{~g} / \mathrm{kg}$ body weight glucose. $n=10$ for Ezh2 ${ }^{\mathrm{f} / \mathrm{f}}$, and $n=13$ for $\beta E z h 2 K O$ mice. $(D)$ Area under curve (AUC) from $C$. (E) Plasma insulin levels at indicated times following glucose injections in 1-mo-old control Ezh2 $2^{\mathrm{f} / \mathrm{f}}$ and $\beta$ Ezh2KO mice. $n=6$ mice for each group. $(F)$ Total pancreas insulin content of control Ezh2 ${ }^{\mathrm{f} / \mathrm{f}}$ and $\beta E z h 2 K O$ mice measured at the indicated ages. $n=5-8$ mice per group. (G) Pancreatic $\beta$-cell mass of Ezh2 ${ }^{\mathrm{f} / \mathrm{f}}$ and $\beta E z h 2 K O$ mice at the indicated ages. $n=4-6$ mice for each group. $(H)$ Representative images showing BrdU (red) and insulin (green) immunostaining in pancreatic islets from 1-mo-old mice after injection with BrdU. BrdU ${ }^{+}$cells, not costained with insulin, were not counted as BrdU ${ }^{+} \beta$ cells. (I) Quantification of $\mathrm{BrdU}^{+}$insulin $^{+}$cells as a percentage of all insulin ${ }^{+}$cells. $n=5$ mice for each group. In total, at least 200 islets per genotype were investigated. $A$ and $I$ are box-whisker plots. $\left({ }^{\star}\right) P<0.05,\left({ }^{\star \star}\right) P<0.01,\left({ }^{\star \star \star}\right) P<0.001$ for Ezh2 $2^{\mathrm{f} / \mathrm{f}}$ versus $\beta$ Ezh2KO. Bar, $25 \mu \mathrm{m}$.

and mass in STZ-challenged $\beta$ Ezh2KO mice. $\beta$-Cell mass reduction was indistinguishable in $\beta E z h 2 K O$ mice and control mice $5 \mathrm{~d}$ after STZ challenge (Fig. 7F), consistent with the view that STZ sensitivity was similar in both mouse groups. BrdU incorporation was markedly increased in $\beta$ cells from controls compared with $\beta$ Ezh2KO islets (Fig. 7D,E). In contrast, BrdU incorporation in acinar cells from both groups of mice was indistinguishable (Fig. 7E). Consistent with this finding, $\beta$-cell mass from 2 to 8 wk after STZ challenge was significantly increased in control mice compared with $\beta$ Ezh2KO mice (Fig. 7F). After STZ challenge, $\beta$ Ezh2KO developed severe diabetes that persisted throughout the $9 \mathrm{wk}$ course of our studies, with average blood glucose levels exceeding $500 \mathrm{mg} / \mathrm{dL}$ during ad libitum feeding (Fig. 7G,H). In contrast, control mice became moderately diabetic after STZ challenge but had clearly improved glucose control and survival by 3-4 wk and thereafter (Fig. 7G,H), coinciding with increases of $\beta$-cell mass (Fig. 7F). Thus, Ezh2 is required for compensatory regeneration of $\beta$ cells in response to STZ-induced diabetes.

\section{Discussion}

Establishment and maintenance of appropriate $\beta$-cell growth and mass is crucial for metabolic balance; thus, the molecular mechanisms governing $\beta$-cell proliferation are the focus of intensive studies. The first postnatal months of life in mice, and the first years of life in humans, are crucial periods of islet $\beta$-cell expansion 
A

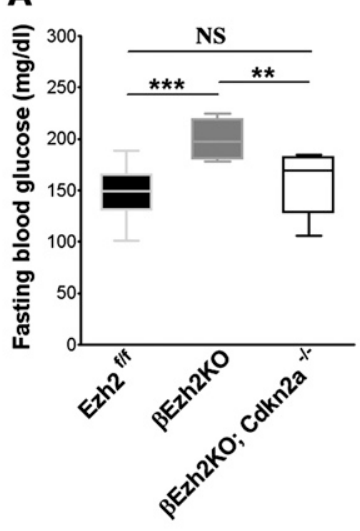

B

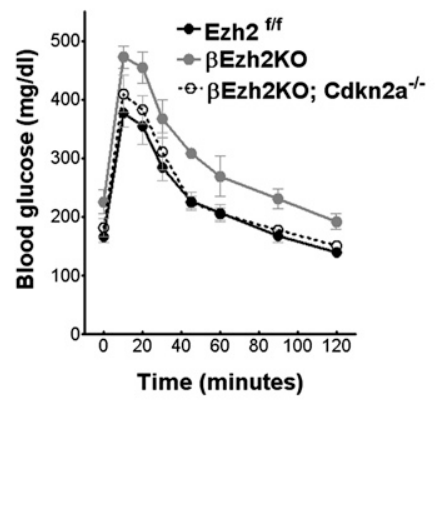

C

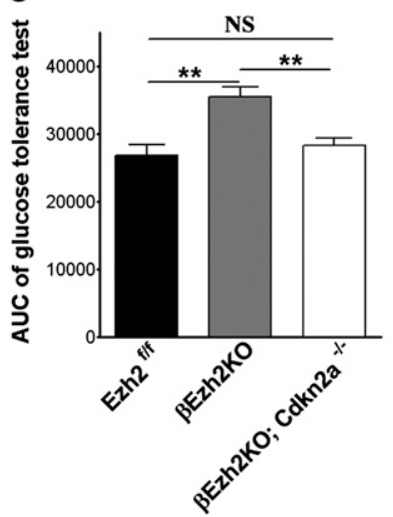

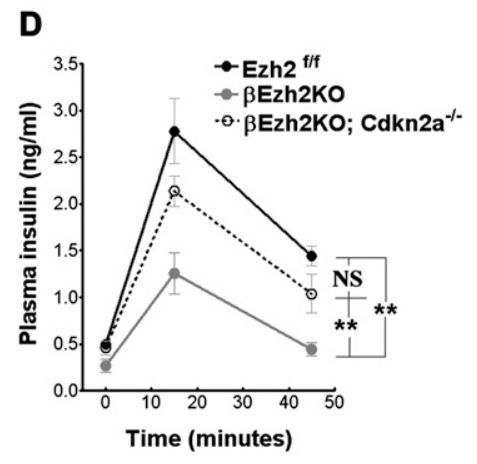

$\mathbf{E}$

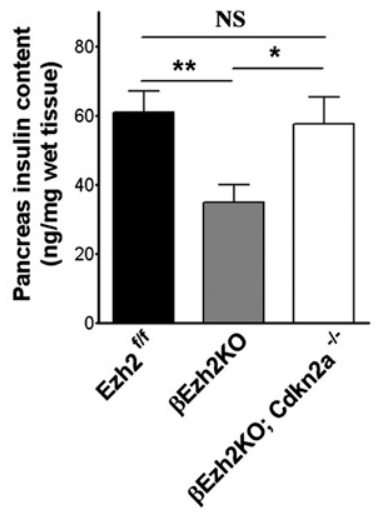

$\mathbf{F}$

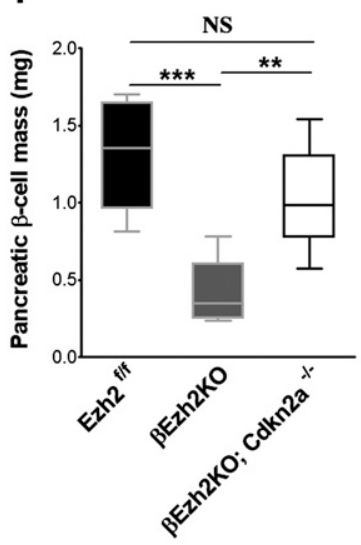

G

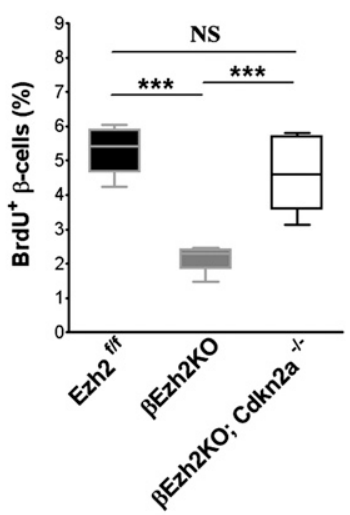

Figure 6. Germline deletion of Cdkn2a rescues glucose metabolism and $\beta$-cell proliferation defects in $\beta$ Ezh2KO mice. (A) Fasting blood glucose in male triple knockout mice lacking Ezh2 in $\beta$ cells and Ink4a/Arf (designated as $\beta E z h 2 \mathrm{KO}$; Cdkn2a ${ }^{-1-}$ ), and $\beta E z h 2 K O$ and littermate control Ezh2 ${ }^{\mathrm{f} / \mathrm{f}}$ mice tested at 1 mo. $n=6-11$ for each group. $(B)$ Glucose tolerance testing. (C) Area under curve (AUC) from $B$. $(D)$ Plasma insulin levels at the indicated times following glucose injections assessed in 1-mo-old mice after overnight fasting. $n=5-6$ for each group. $(E-G)$ Total pancreas insulin content $(E)$, pancreatic $\beta$-cell mass $(F)$, and quantification of BrdU ${ }^{+}$insulin ${ }^{+}$cells as a percentage of all insulin ${ }^{+}$cells $(G)$ in male triple knockout $\beta E z h 2 K O ; C d k n 2 a^{-1-}$ mice, and $\beta E z h 2 K O$ and littermate control Ezh2 ${ }^{\mathrm{f} / \mathrm{f}}$ mice at 1 mo. $n=3-4$ mice for each group. $A, F$, and $G$ are box-whisker plots. $\left({ }^{*}\right) P<0.05,\left(^{\star \star}\right) P<0.01,\left({ }^{\star \star}\right) P<0.001$. (NS) Not significant.

that result in establishment of appropriate $\beta$-cell mass (Georgia and Bhushan 2004; Kushner et al. 2005; Teta et al. 2005; Meier et al. 2008). While prior studies had linked Ink4a/Arf induction with attenuated islet $\beta$-cell growth in aging (Krishnamurthy et al. 2006), the roles of these cell cycle regulators during $\beta$-cell expansion in juvenile animals and the mechanisms governing their expression had not been identified. Thus, our demonstration that Ink4a/Arf derepression upon Ezh2 loss can induce replication failure of islet $\beta$ cells in neonatal mice provides unique evidence for PcG regulation of physiological islet cell growth.

Ezh2 and the PRC2 complex regulate expression of multiple targets throughout the genome (Kamminga et al. 2006; Bracken et al. 2007); thus, prior to our studies, it was unclear if Ezh2 regulation of Ink4a/Arf expression was the basis for proliferative failure in islet $\beta$ cells following Ezh2 loss. In this study, we found that deficiency of Ink4a/Arf expression by deletion of the $C d k n 2 a$ locus prevents islet $\beta$-cell hypoplasia in mice with conditional $\beta$-cell Ezh2 loss. This finding supports the view that Ezh2 controls neonatal islet $\beta$-cell expansion in juvenile mice by directly regulating Ink4a/Arf. Following Ezh2 loss, we found increased histone H3K4 trimethylation at the Ink $4 a /$ Arf locus, an epigenetic mark known to be regulated by nuclear protein complexes containing the trithorax group (TrxG) protein MLL (Hughes et al. 2004; Yokoyama et al. 2004). Consistent with these results, Dhawan et al. (2009) found that MLL association with Ink4a/Arf increased with aging. Collectively, these findings suggest that multiple dynamic histone modifications likely regulate expression of Ink4a/Arf and replication in islet cells.

$\beta$-Cell proliferation declines rapidly in juvenile mice and humans, followed by a sustained slower reduction in adulthood (Teta et al. 2005; Meier et al. 2008). Accompanying these two phases of proliferative attenuation, we observed a reduction of Ezh2 mRNA in islet $\beta$ cells of both species (Figs. 1, 2). Our studies with $\beta E z h 2 K O$ mice show that premature Ezh2 loss leads to induction of the 

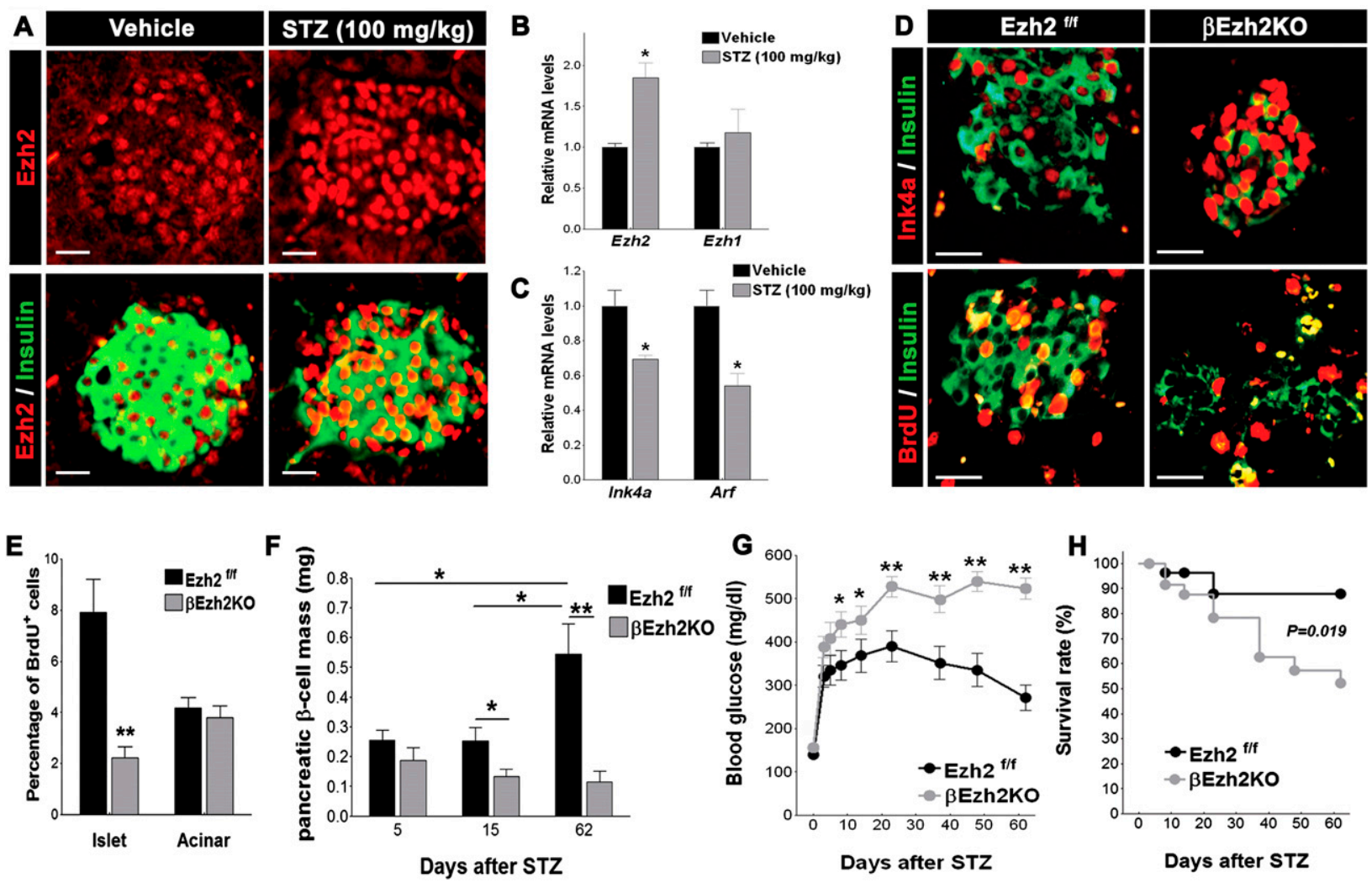

Figure 7. Failure of $\beta$-cell regeneration and recovery from STZ-induced diabetes in $\beta$ Ezh2KO mice. $(A)$ Representative images of pancreatic islets and adjacent tissues following immunostaining for Ezh2 and insulin in 6-wk-old Ezh2 ${ }^{\mathrm{f} / \mathrm{f}}$ mice $15 \mathrm{~d}$ after receiving a single intraperitoneal injection of sodium citrate (Vehicle) or STZ $(100 \mathrm{mg} / \mathrm{kg}$ body weight). Relative to the Vehicle group, STZ induces a high level of Ezh2 expression in insulin ${ }^{+}$cells. $(B, C)$ Relative mRNA levels of Ezh2, Ezh1(B) and Ink4a, Arf $(C)$ in islets from 6-wk-old Ezh2 ${ }^{\mathrm{f} / \mathrm{f}}$ mice $6 \mathrm{~d}$ after vehicle or STZ treatment. $n=4-5$ mice per group. $(D)$ Representative images showing Ink4a/insulin and BrdU/ insulin immunostaining in pancreatic islets from 6-wk-old Ezh2 ${ }^{\mathrm{f} / \mathrm{f}}$ and $\beta E z h 2 \mathrm{KO}$ mice $15 \mathrm{~d}$ after STZ treatment. $(E)$ Quantification of $\mathrm{BrdU}^{+}$cells as a percentage in all insulin ${ }^{+}$cells (Islet) or in noninsulin ${ }^{+}$cells (Acinar) from $D . n=3$ or 4 mice for each group. $(F)$ Pancreatic $\beta$-cell mass of Ezh2/f/f and $\beta E z h 2 K O$ mice assessed at 5, 15, and $62 \mathrm{~d}$ after STZ treatment. $n=3$ or 4 mice for each group. (G) Blood glucose levels in Ezh2 ${ }^{\mathrm{f} / \mathrm{f}}$ and $\beta E z h 2 K O$ mice after STZ treatment. $(H)$ Percentage survival after STZ treatment. $n=24$ for Ezh2 ${ }^{\mathrm{f} / \mathrm{f}}$ and $n=20$ for $\beta E z h 2 K O$ in $G$ and $H$. The dose of STZ injection was $150 \mathrm{mg} / \mathrm{kg}$ body weight from $D$ to $H .\left(^{*}\right) P<0.05,\left(^{\star \star}\right) P<0.01$ for comparison between vehicle versus STZ, Ezh2 ${ }^{\mathrm{f} / \mathrm{f}}$ versus $\beta E z h 2 K O$, or for comparison as indicated. Bar, $25 \mu \mathrm{m}$.

Ezh2 targets Ink4a and Arf in juvenile mice, impaired $\beta$-cell proliferation and expansion, and persistent mild diabetes. While these results are consistent with the possibility that Ezh2 loss may regulate reductions of $\beta$-cell proliferation in the neonatal period, our finding that islet Ink $4 a / A r f$ expression increases in adult $\beta E z h 2 \mathrm{KO}$ mice suggests that factors other than Ezh2 regulate Ink4a/Arf to limit $\beta$-cell proliferation in aging. Thus, Ezh2 is unlikely to be the sole or limiting molecular determinant of replicative senescence in adult mouse $\beta$ cells.

Islet $\beta$ cells proliferate to meet systemic demands (for review, see Heit et al. 2006a). Following STZ-induced $\beta$-cell destruction, expression of Ezh2 in surviving $\beta$ cells increased, leading to suppression of Ink4a levels. Moreover, impaired $\beta$-cell regeneration and lethal diabetes in $\beta$ Ezh2KO mice argue that Ezh2 is required for adaptive $\beta$-cell proliferation. Thus our work reveals that in neonates and in the pathological setting of STZ-induced diabetes, elevated Ezh2 levels accompany $\beta$-cell proliferation. Supporting the hypothesis that Ezh2 may regulate general physiological or regenerative $\beta$-cell growth, we recently observed increased Ezh2 expression in maternal islets during pregnancy (H. Chen and S.K. Kim, unpubl.), a state characterized by adaptive $\beta$-cell expansion in mice and humans (Karnik et al. 2007). These findings motivate further studies to identify signaling pathways that regulate $\beta$-cell Ezh2 expression. Additional studies are also needed to test if enhanced Ezh2 levels or function might promote $\beta$-cell growth in aging and other states associated with $\beta$-cell failure and increased diabetes risk. If so, then understanding the epigenetic mechanisms governing islet self-renewal may accelerate development of strategies for islet replacement or regeneration.

In conclusion, our work, together with studies of Dhawan et al. (2009) on Bmi-1 and prior studies on the tumor suppressor protein menin (Karnik et al. 2005, 2007), provides unique evidence that histone modifications, regulated by protein complexes containing TrxG proteins and PcG proteins, are required to repress genes encoding $\beta$-cell cycle inhibitors, thereby permitting 
physiological and adaptive $\beta$-cell expansion. Collectively, these studies argue that dynamic epigenetic regulation orchestrated by PcG and TrxG protein complexes controls $\beta$-cell growth and differentiation.

\section{Materials and methods}

\section{Animals and genotyping}

Ezh2 ${ }^{\mathrm{f} / \mathrm{f}}$ mice with loxP sites flanking exons 16 to 19 of the Ezh2 gene and RIP-Cre mice expressing Cre recombinase from rat insulin 2 gene promoter elements were described previously (Herrera 2000; Su et al. 2003; Heit et al. 2006b). These two strains were intercrossed to generate RIP-Cre; Ezh2 ${ }^{\mathrm{f} / \mathrm{f}}$ mice $(\beta E z h 2 \mathrm{KO})$ mice together with their littermate controls on a mixed $129 / \mathrm{Sv}$; C57BL/6 genetic background. Cdkn2a $\mathrm{a}^{-1-}$ mice on a C57BL/6 genetic background carried a targeted deletion of exons $2 / 3$ of the $C d k n 2 a$ gene that eliminates both Ink $4 a$ and Arf expression (Serrano et al. 1996), and were obtained from Mouse Models of Human Cancers Consortium at the National Cancer Institute (NCI), USA. Triple knockout mice lacking Ezh2 in $\beta$ cells, Ink $4 a$, and Arf were produced from subsequent intercrosses between Cdkn $2 \mathrm{a}^{-/-}$and $\beta E z h 2 K O$ mice. All mice were genotyped routinely by PCR of tail genomic DNA for floxed Ezh2, Cdkn2a alleles and the RIP-Cre transgene as previously described. Mice used in this study were age- and gender-matched littermates. Inbred C57BL/6 mice were purchased from the National Cancer Institute (NCI). All mice were housed in a pathogen-free environment on a 12-h light/dark cycle with ad libitum access to water and normal chow in the animal facility of Stanford University. All animal experiments and methods were approved by the Institutional Animal Care and Use Committee (IACUC) of Stanford University.

\section{Real-time RT-PCR and Western blot analysis}

Mouse pancreatic islets were isolated and purified by a standard procedure (Chen et al. 2001). Total RNA from isolated islets was purified using the Absolutely RNA miniprep purification kit (Stratagene) according to the manufacturer's instructions, and the RNA concentration was measured with a RiboGreen RNA quantification assay (Invitrogen). One-step quantitative RT-PCR was performed and analyzed using an ABI Prism 7300 detection system (Applied Biosystems) with TaqMan one-step RT-PCR Master Mix Reagents and appropriate amounts (10 to $100 \mathrm{ng}$ ) of islet total RNA as the template. We calculated the ratio of mRNA for the gene of interest to the amount of internal control mRNA of peptidylprolyl isomerase A (cyclophilin A, PPIA), and then normalized the ratio for each gene to its median. Primer and probe sequences are listed in Supplemental Table 1. For Western blots, total islet protein was prepared as described previously (Chen et al. 2005). Equal amounts of protein were resolved on SDS-PAGE and transferred to polyvinylidine fluoride membranes (Amersham Pharmacia) for immunoblotting with specific antibodies, including rabbit polyclonal anti-human EZH2 (1:1000; Upstate Biotechnologies), mouse monoclonal anti-INK4a (1: 2000; Santa Cruz Biotechnologies) and mouse monoclonal anti$\beta$-actin (1:4000; Sigma). Signal was visualized using the ECL detection system (Amersham Pharmacia) on Kodak film after further incubation with HRP-conjugated secondary antibodies.

\section{Physiological studies}

After weaning mice, we monitored body weight and blood glucose levels in ad libitum fed mice, after $16 \mathrm{~h}$ of overnight fasting, and $1 \mathrm{~h}$ after refeeding (" $1 \mathrm{~h}$ post-prandial") at the ages indicated in the text and figures. We used the OneTouch Ultra glucose meter (LifeScan) to measure glucose levels in blood from tail vein punctures.

Glucose tolerance tests were performed on mice after a 16-h overnight fast, and the blood glucose levels were determined immediately before $(0)$ and 5, 10, 20, 30, 45, 60, 90, and $120 \mathrm{~min}$ after intraperitoneal injection of glucose $(2 \mathrm{~g} / \mathrm{kg}$ or $3 \mathrm{~g} / \mathrm{kg}$ body weight as indicated). For measurement of plasma insulin levels during these glucose tolerance tests, we collected tail vein blood at 0,15 , and $45 \mathrm{~min}$ after $3 \mathrm{~g} / \mathrm{kg}$ body weight of glucose injection. We measured insulin levels using a mouse insulin ELISA kit (ALPCO diagnostics). For insulin tolerance tests, mice were fasted for $6 \mathrm{~h}$ then received intraperitoneal injection of $0.75 \mathrm{U} / \mathrm{kg}$ body weight of insulin (Sigma); glucose levels at 0, 10, $20,30,40,60$, and $90 \mathrm{~min}$ after injection were then measured.

For the measurement of total pancreas insulin content, the whole pancreas was removed from the animal at the specific ages, then homogenized and extracted with acid ethanol $175 \%$ ethanol: $\left.2 \% \mathrm{HCl}: 23 \% \mathrm{H}_{2} \mathrm{O}[\mathrm{v} / \mathrm{v} / \mathrm{v}]\right)$ overnight at $4^{\circ} \mathrm{C}$. Insulin content was measured in the diluted extraction solution using a mouse insulin ELISA kit. We injected some male mice intraperitoneally at $4 \mathrm{wk}$ of age with $\mathrm{BrdU}(100 \mathrm{mg} / \mathrm{kg}$; Sigma) once every day for $3 \mathrm{~d}$. Pancreata were harvested for histology and immunostaining of BrdU and morphormetric counting of $\beta$-cell proliferation rate, as described previously (Heit et al. 2006b).

\section{In vivo STZ treatment and BrdU incorporation}

Mice of the indicated genotypes, including gender-matched controls, aged 5-7 wk, were treated with a single intraperitoneal injection of freshly dissolved STZ (Sigma; $150 \mathrm{mg} / \mathrm{kg}$ or $100 \mathrm{mg}$ / $\mathrm{kg}$ body weight as indicated) in $0.1 \mathrm{~mol} / \mathrm{L}$ sodium citrate ( $\mathrm{pH} 4.5)$. After injection, blood samples were taken from a tail clip, and glucose values were measured every other $2 \mathrm{~d}$ in the first week and thereafter once per week. Mouse deaths were recorded, with exclusion of acute STZ-induced death (defined as death within $2 \mathrm{~d}$ after STZ injection). After $1 \mathrm{wk}$ of STZ treatment, some Ezh2/f/f and $\beta E z h 2 K O$ littermates were fed with BrdU-containing drinking water $(1 \mathrm{mg} / \mathrm{mL})$ for $1 \mathrm{wk}$, followed by immunostaining of pancreas sections for BrdU incorporation and insulin protein. Some Ezh2 ${ }^{\mathrm{f} / \mathrm{f}}$ mice were treated with $100 \mathrm{mg} / \mathrm{kg}$ body weight of STZ or with the same amount of sodium citrate (vehicle) for $6 \mathrm{~d}$ followed by islet isolation for gene expression studies. Five days, $15 \mathrm{~d}$, and $62 \mathrm{~d}$ after STZ (or vehicle) treatment, other animals were sacrificed to obtain pancreata for histology and immunostaining of Ezh2, Ink4a, and insulin.

\section{Histology, immunofluorescence, and immunohistochemistry}

We used a standard paraformaldehyde fixation, paraffin-embedding, and immunostaining protocol, except for Ink4a detection. For Ink4a immunohistology, the pancreas was fixed in Fekete's acid alcohol solution $(61 \%$ ethanol, $4.3 \%$ glacial acetic acid, and $3.5 \%$ formalin) as described previously (Krishnamurthy et al. 2004). Immunohistochemical analysis was performed on $5-\mu \mathrm{m}$ thick sections of pancreatic tissues after antigen retrieval (DAKO) and using the following primary antibodies: guinea pig anti-pig insulin (1:400; Sigma), rabbit anti-Ezh2 (1:100; Epigentek), mouse monoclonal anti-INK4a (1:50; Santa Cruz Biotechnologies), and mouse monoclonal anti-BrdU (Amersham Pharmacia). We detected immune complexes with secondary antibodies conjugated with either $\mathrm{Cy} 3$, fluorescein isothiocyanate (Jackson ImmunoResearch), or horseradish peroxidase (Vector Laboratories). For measuring pancreatic $\beta$-cell mass or BrdU by morphometry, four or six mice of each genotype at every age were analyzed. At least five sections separated by more than 300 
$\mu \mathrm{m}$ were immunostained and assessed for each mouse. Images were analyzed with ImagePro program, and pancreatic $\beta$-cell mass and percentage of BrdU-positive $\beta$ cells were calculated as described previously (Heit et al. 2006b).

\section{Islet insulin secretion and islet insulin content measurement}

We cultured isolated islets overnight in standard media, then used these for batch incubation experiments to detect glucoseand arginine-stimulated insulin secretion, as described previously (Chen et al. 2001; Rulifson et al. 2007). Briefly, in a microplate, five islets of similar size were handpicked into each well with modified Krebs-Ringer bicarbonate buffer (KRBB) containing $3 \mathrm{mM}$ glucose. After washes, islets were incubated consecutively in the indicated low and high levels of glucose or arginine KRBB for $1 \mathrm{~h}$. Islet total insulin was extracted with acid ethanol. Insulin level was measured with a mouse insulin ELISA kit (ALPCO Diagnostics). Islet DNA was quantified with PicoGreen (Invitrogen) to normalize insulin levels.

\section{Pancreatic islet ChIP analysis}

ChIPs were performed using a ChIP kit from Upstate Biotechnologies. Briefly, freshly isolated pancreatic islets were pooled and treated with $2 \%$ formaldehyde for cross-linking for $20 \mathrm{~min}$ at room temperature. After washing, islets were dissolved in SDS lysis buffer containing a proteinase inhibitor cocktail followed by sonication to shear chromatin. Precleared chromatin from 150300 islets was used for each ChIP sample with incubation of 1 to $5 \mu \mathrm{g}$ of the appropriate antibodies overnight at $4^{\circ} \mathrm{C}$. The antibodies used in the ChIP assays included rabbit anti-Ezh2, rabbit anti-trimethyl-Histone $\mathrm{H} 3$ (Lys27), rabbit anti-trimethyl-Histone H3 (Lys4), rabbit anti-trimethyl-Histone H3 (Lys9), rabbit antiacetyl-Histone H3 (Lys9/14) (Upstate Biotechnologies), and rabbit polyclonal IgG (Santa Cruz Biotechnologies, catalog no. SC-805, used for the "IgG control"). After incubation, the immunoprecipitated chromatin DNA was harvested, cross-link reversed, and purified. After measurement of DNA concentration by PicoGreen DNA assay (Invitrogen), equivalent amounts of chromatin DNA from every sample were quantified by realtime quantitative PCR in the ABI Prism 7300 detection system (Applied Biosystems). The PCR primer and probe sequences are listed in Supplemental Table 2.

\section{Gene expression in human pancreatic islets and pancreas} sections

Frozen or fresh isolated pancreatic islets were recovered from donors with appropriate consent at the University of Alabama at Birmingham Islet Cell Resource Center. Human islet mRNA levels for EZH2 and SUZ12 were measured by real-time RT-PCR using the similar protocols used for mouse islets, except we used human gene-specific primers and probes as follows: human EZH2: forward, 5'-TTGCCAAGAGAGCCATCCA-3', reverse, 5'-GCATCAGCCTGGCTGTATCTG-3', and probe, 5' -ACTGG CGAAGAGCTGTTTTTTGA-3'; human SUZ12: forward, 5'GGATCCTGAATGGCTAAGAGAAAAA-3', reverse, 5' - TCAT CACTTCTTTCTCTCСТTCATTAAC-3', and probe, 5'-CCAT TACACAAATTGAAGAGTTTTCTGA-3'; and human peptidylprolyl isomerase A (cyclophilin A, PPIA): forward, 5' -ATAAGGG TTCCTGCTTTCACAGAA-3', reverse, 5' -GCCATTATGGCGT GTGAAGTC-3', and probe, 5' - TCCAGGGTTTATGTGTCAG GGTG-3'. Pancreas sections from six normal human subjects at the age of 2, 4, 5, 64, 75, $79 \mathrm{yr}$ old, respectively, were obtained at the University of Pittsburgh. The immunohistology methods for detecting EZH2 and INK4A were similar to that used for mouse pancreas tissues as described above, except that the antigen retrieval step was performed in citrate buffer $(10 \mathrm{mM}$ citric acid, $0.05 \%$ Tween 20 at $\mathrm{pH} 6.0)$ for $20 \mathrm{~min}$ at $95^{\circ} \mathrm{C}$ for $\mathrm{EZH} 2$ staining. Immunostaining of EZH2 and INK4A was repeated on at least three sections for every donor pancreas.

\section{Statistical analysis}

Results were expressed as the mean $\pm \mathrm{SE}$, or shown by boxwhisker plots indicating median, 25th to 75 th percentile (boxes) and entire range (whiskers). Statistical analysis was performed with one-way ANOVA, two-way repeated measures ANOVA, unpaired Student's $t$-test, or log-rank survival test. Differences were considered to be significant at $P<0.05$.

\section{Acknowledgments}

We thank Drs. H. Chang, J. Wysocka, J. Sage, and X. Li for helpful discussions and advice; Dr. P. Herrera for mice; the Islet Resources Centers Consortium for materials; Dr. A. Bhushan for communicating unpublished studies; and members of the Kim laboratory for comments on the manuscript. H.C. was supported by the NIH Ruth L. Kirschstein NRSA/Stanford Regenerative Medicine Training Program. Work in the Kim laboratory was supported by the NIH, the Snyder Foundation, the Larry L. Hillblom Foundation, and the Juvenile Diabetes Research Foundation. S.K.K. is an investigator in the Howard Hughes Medical Institute. H.C. and S.K.K. generated hypotheses and designed experiments. R.B. and J.L.C. obtained human tissues and cells. I-H.S. and A.T. generated Ezh2 $2^{f}$ mice. H.C. and X.G. performed experiments. H.C. and S.K.K. wrote the manuscript.

\section{References}

Alonso, L.C., Yokoe, T., Zhang, P.L., Scott, D.K., Kim, S.K., O'Donnell, C.P., and Garcia-Ocana, A. 2007. Glucose infusion in mice-A new model to induce $\beta$-cell replication. Diabetes 56: 1792-1801.

Bracken, A.P., Pasini, D., Capra, M., Prosperini, E., Colli, E., and Helin, K. 2003. EZH2 is downstream of the pRB-E2F pathway, essential for proliferation and amplified in cancer. EMBO J. 22: 5323-5335.

Bracken, A.P., Kleine-Kohlbrecher, D., Dietrich, N., Pasini, D., Gargiulo, G., Beekman, C., Theilgaard-Monch, K., Minucci, S., Porse, B.T., Marine, J.C., et al. 2007. The Polycomb group proteins bind throughout the INK4A-ARF locus and are disassociated in senescent cells. Genes \& Dev. 21: 525530.

Cao, R., Wang, L.J., Wang, H.B., Xia, L., Erdjument-Bromage, H., Tempst, P., Jones, R.S., and Zhang, Y. 2002. Role of histone H3 lysine 27 methylation in polycomb-group silencing. Science 298: 1039-1043.

Chen, H.N., Carlson, E.C., Pellet, L., Moritz, J.T., and Epstein, P.N. 2001. Overexpression of metallothionein in pancreatic $\beta$-cells reduces streptozotocin-induced DNA damage and diabetes. Diabetes 50: 2040-2046.

Chen, H.N., Li, X.Y., and Epstein, P.N. 2005. MnSOD and catalase transgenes demonstrate that protection of islets from oxidative stress does not alter cytokine toxicity. Diabetes 54: 1437-1446.

Cozar-Castellano, I., Fiaschi-Taesch, N., Bigatel, T.A., Takane, K.K., Garcia-Ocana, A., Vasavada, R., and Stewart, A.F. 2006. Molecular control of cell cycle progression in the pancreatic $\beta$-cell. Endocr. Rev. 27: 356-370. 
Dhawan, S., Tschen, S.-I., and Bhushan, A. 2009. Bmi-1 regulates the Ink $4 a / A r f$ locus to control pancreatic $\beta$-cell proliferation. Genes \& Dev. (this issue). doi: 10.1101/gad.1742609.

Georgia, S. and Bhushan, A. 2004. $\beta$ cell replication is the primary mechanism for maintaining postnatal $\beta$ cell mass. J. Clin. Invest. 114: 963-968.

Grarup, N., Rose, C.S., Andersson, E.A., Andersen, G., Nielsen, A.L., Albrechtsen, A., Clausen, J.O., Rasmussen, S.S., Jorgensen, T., Sandbaek, A., et al. 2007. Studies of association of variants near the HHEX, CDKN2A/B, and IGF2BP2 genes with type 2 diabetes and impaired insulin release in 10,705 Danish subjects-Validation and extension of genome-wide association studies. Diabetes 56: 3105-3111.

Heit, J.J., Karnik, S.K., and Kim, S.K. 2006a. Intrinsic regulators of pancreatic $\beta$-cell proliferation. Annu. Rev. Cell Dev. Biol. 22: $311-338$.

Heit, J.J., Apelqvist, A.A., Gu, X.Y., Winslow, M.M., Neilson, J.R., Crabtree, G.R., and Kim, S.K. 2006b. Calcineurin/NFAT signalling regulates pancreatic $\beta$-cell growth and function. Nature 443: 345-349.

Herrera, P.L. 2000. Adult insulin- and glucagon-producing cells differentiate from two independent cell lineages. Development 127: 2317-2322.

Hughes, C.M., Rozenblatt-Rosen, O., Milne, T.A., Copeland, T.D., Levine, S.S., Lee, J.C., Hayes, D.N., Shanmugam, K.S., Bhattacharjee, A., Biondi, C.A., et al. 2004. Menin associates with a trithorax family histone methyltransferase complex and with the Hoxc8 locus. Mol. Cell 13: 587-597.

Kamminga, L.M., Bystrykh, L.V., Boer, A.C., Houwer, S., Douma, J., Weersing, E., Dontje, B., and de Haan, G. 2006. The polycomb group gene Ezh2 prevents hematopoietic stem cell exhaustion. Blood 107: 2170-2179.

Karnik, S.K., Hughes, C.M., Gu, X.Y., Rozenblatt-Rosen, O., Mclean, G.W., Xiong, Y., Meyerson, M., and Kim, S.K. 2005. Menin regulates pancreatic islet growth by promoting histone methylation and expression of genes encoding p27(Kip1) and p18(INK4c). Proc. Nat1. Acad. Sci. 102: 14659-14664.

Karnik, S.K., Chen, H.N., Mclean, G.W., Heit, J.J., Gu, X.Y., Zhang, A.Y., Fontaine, M., Yen, M.H., and Kim, S.K. 2007. Menin controls growth of pancreatic $\beta$-cells in pregnant mice and promotes gestational diabetes mellitus. Science 318: 806-809.

Kim, W.Y. and Sharpless, N.E. 2006. The regulation of INK4/ ARF in cancer and aging. Cell 127: 265-275.

Krishnamurthy, J., Torrice, C., Ramsey, M.R., Kovalev, G.I., Al Regaiey, K., Su, L.S., and Sharpless, N.E. 2004. Ink4a/Arf expression is a biomarker of aging. J. Clin. Invest. 114: 12991307.

Krishnamurthy, J., Ramsey, M.R., Ligon, K.L., Torrice, C., Koh, A., Bonner-Weir, S., and Sharpless, N.E. 2006. p16(INK4a) induces an age-dependent decline in islet regenerative potential. Nature 443: 453-457.

Kushner, J.A., Ciemerych, M.A., Sicinska, E., Wartschow, L.M., Teta, M., Long, S.Y., Sicinski, P., and White, M.F. 2005. Cyclins D2 and D1 are essential for postnatal pancreatic $\beta$-cell growth. Mol. Cell. Biol. 25: 3752-3762.

Matheu, A., Maraver, A., and Serrano, M. 2008. The Arf/p53 pathway in cancer and aging. Cancer Res. 68: 6031-6034.

Meier, J.J., Butler, A.E., Saisho, Y., Monchamp, T., Galasso, R., Bhushan, A., Rizza, R.A., and Butler, P.C. 2008. $\beta$-Cell replication is the primary mechanism subserving the postnatal expansion of $\beta$-cell mass in humans. Diabetes 57: 1584-1594.

Metsuyanim, S., Pode-Shakked, N., Schmidt-Ott, K.M., Keshet, G., Rechavi, G., Blumental, D., and Dekel, B. 2008. Accu- mulation of malignant renal stem cells is associated with epigenetic changes in normal renal progenitor genes. Stem Cells 26: $1808-1817$.

Nielsen, G.P., Stemmer-Rachamimov, A.O., Shaw, J., Roy, J.E., Koh, J., and Louis, D.N. 1999. Immunohistochemical survey of p16(INK4A) expression in normal human adult and infant tissues. Lab. Invest. 79: 1137-1143.

Omori, S., Tanaka, Y., Takahashi, A., Hirose, H., Kashiwagi, A., Kaku, K., Kawamori, R., Nakamura, Y., and Maeda, S. 2008. Association of Cdkal1, Igf2Bp2, Cdkn2A/B, Hhex, Slc30A8, and Kcnj11 with susceptibility to Type 2 diabetes in a Japanese population. Diabetes 57: 791-795.

Rane, S.G., Dubus, P., Mettus, R.V., Galbreath, E.J., Boden, G., Reddy, E.P., and Barbacid, M. 1999. Loss of Cdk4 expression causes insulin-deficient diabetes and Cdk 4 activation results in $\beta$-islet cell hyperplasia. Nat. Genet. 22: 44-52.

Ringrose, L. and Paro, R. 2007. Polycomb/Trithorax response elements and epigenetic memory of cell identity. Development 134: 223-232.

Rulifson, I.C., Karnik, S.K., Heiser, P.W., Ten Berge, D., Chen, H.N., Gu, X.Y., Taketo, M.M., Nusse, R., Hebrok, M., and Kim, S.K. 2007. Wnt signaling regulates pancreatic $\beta$ cell proliferation. Proc. Natl. Acad. Sci. 104: 6247-6252.

Saxena, R., Voight, B.F., Lyssenko, V., Burtt, N.P., de Bakker, P.I.W., Chen, H., Roix, J.J., Kathiresan, S., Hirschhorn, J.N., Daly, M.J., et al. 2007. Genome-wide association analysis identifies loci for type 2 diabetes and triglyceride levels. Science 316: 1331-1336.

Scott, L.J., Mohlke, K.L., Bonnycastle, L.L., Willer, C.J., Li, Y., Duren, W.L., Erdos, M.R., Stringham, H.M., Chines, P.S., Jackson, A.U., et al. 2007. A genome-wide association study of type 2 diabetes in Finns detects multiple susceptibility variants. Science 316: 1341-1345.

Serrano, M., Lee, H.W., Chin, L., CordonCardo, C., Beach, D., and DePinho, R.A. 1996. Role of the INK4a locus in tumor suppression and cell mortality. Cell 85: 27-37.

Sparmann, A. and van Lohuizen, M. 2006. Polycomb silencers control cell fate, development and cancer. Nat. Rev. Cancer 6: $846-856$.

Su, I.H., Basavaraj, A., Krutchinsky, A.N., Hobert, O., Ullrich, A., Chait, B.T., and Tarakhovsky, A. 2003. Ezh2 controls B cell development through histone $\mathrm{H} 3$ methylation and Igh rearrangement. Nat. Immunol. 4: 124-131.

Teta, M., Long, S.Y., Wartschow, L.M., Rankin, M.M., and Kushner, J.A. 2005. Very slow turnover of $\beta$-cells in aged adult mice. Diabetes 54: 2557-2567.

van der Vlag, J. and Otte, A.P. 1999. Transcriptional repression mediated by the human polycomb-group protein EED involves histone deacetylation. Nat. Genet. 23: 474-478.

Wang, R.N., Bouwens, L., and Kloppel, G. 1996. $\beta$-Cell growth in adolescent and adult rats treated with streptozotocin during the neonatal period. Diabetologia 39: 548-557.

Yokoyama, A., Wang, Z., Wysocka, J., Sanyal, M., Aufiero, D.J., Kitabayashi, I., Herr, W., and Cleary, M.L. 2004. Leukemia proto-oncoprotein MLL forms a SET1-like histone methyltransferase complex with menin to regulate Hox gene expression. Mol. Cell. Biol. 24: 5639-5649.

Zeggini, E., Weedon, M.N., Lindgren, C.M., Frayling, T.M., Elliott, K.S., Lango, H., Timpson, N.J., Perry, J.R.B., Rayner, N.W., Freathy, R.M., et al. 2007. Replication of genome-wide association signals in UK samples reveals risk loci for type 2 diabetes. Science 316: 1336-1341.

Zindy, F., Quelle, D.E., Roussel, M.F., and Sherr, C.J. 1997. Expression of the p16(INK4a) tumor suppressor versus other INK4 family members during mouse development and aging. Oncogene 15: 203-211. 


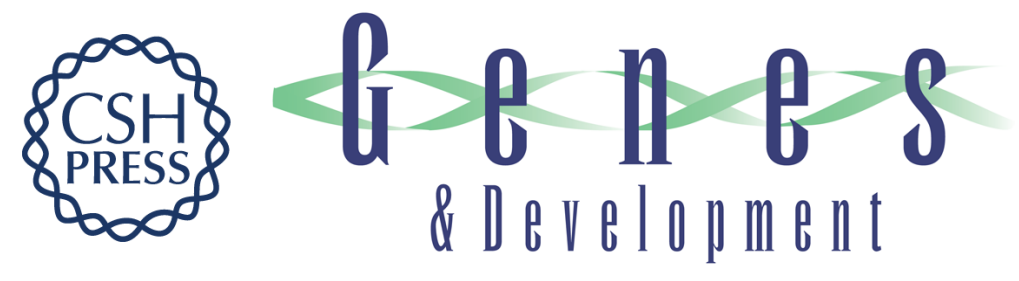

\section{Polycomb protein Ezh2 regulates pancreatic $\beta$-cell Ink4a/Arf expression and regeneration in diabetes mellitus}

Hainan Chen, Xueying Gu, I-hsin Su, et al.

Genes Dev. 2009, 23:

Access the most recent version at doi:10.1101/gad.1742509

Supplemental
Material $\quad$ http://genesdev.cshlp.org/content/suppl/2009/04/16/23.8.975.DC1

References This article cites 40 articles, 23 of which can be accessed free at:

http://genesdev.cshlp.org/content/23/8/975.full.html\#ref-list-1

License

Email Alerting Receive free email alerts when new articles cite this article - sign up in the box at the top

Service right corner of the article or click here.

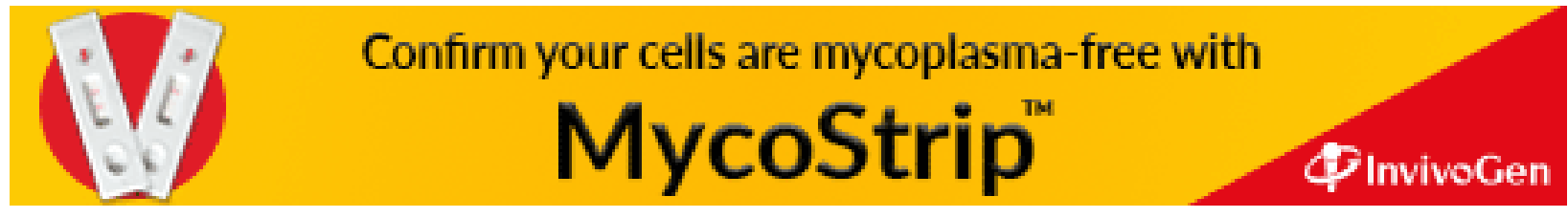

